\title{
China's brick history and conservation: laboratory results of Shanghai samples from 19th to 20th century
}

\author{
C.X. Shu ${ }^{\text {a,* }}$, E. Cantisani ${ }^{\text {b }}$, F. Fratini ${ }^{\text {b }}$, K.L. Rasmussen ${ }^{\text {d }}$, L. Rovero ${ }^{\text {c }}$, G. Stipo ${ }^{\text {c }}$, S. Vettori ${ }^{\text {b }}$

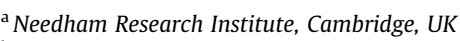 \\ ${ }^{\mathrm{b}}$ CNR-ICVBC (Institute for Conservation and Valorisation of Cultural Heritage), Florence, Italy \\ ${ }^{\mathrm{C}}$ Department of Architecture, Section Materials and Structures, University of Florence, Piazza Brunelleschi 6, 50121 Florence, Italy \\ ${ }^{\mathrm{d}}$ CHART-group, Department of Physics, Chemistry and Pharmacy, Campusvej 55, 5230 Odense M, Denmark
}

\section{H I G H L I G H T S}

- The first inquiry into the provenance of bricks in the Western heritage of China.

- Identified coal-residue bricks and the potential Russian sources.

- Proposed new perspectives on the modern revolution of China's brick history.

- Revealed the present condition of modern Shanghai's bricks for conservation.

\section{A R T I C L E I N F O}

\section{Article history:}

Received 20 December 2016

Received in revised form 12 June 2017

Accepted 16 June 2017

\section{Keywords:}

Shanghai bricks

Building materials

Firing temperature

Brick properties

Conservation

\begin{abstract}
A B S T R A C T
Fired bricks have been used for construction purposes in China for at least two thousand years. Since the mid-19th century the manufacture of bricks has shifted from an old to a new system. The unique Chinese blue brick has been gradually replaced by the European red brick and other modern products. This study focuses on Shanghai as a representative city in that transitional period, aims at addressing the true condition of the modern changes in China's brick history and the heritage today.

The paper presents the first results of an interdisciplinary investigation. Fourteen brick samples and one sample of raw material were studied with regard to the mineralogical, petrographic, chemical, physical, mechanical characteristics, and the maximum firing temperature. It also makes measurements of the presented soluble salts in the altered brick samples.

Preliminary conclusions are drawn with regard to three critical issues: the provenance of the bricks, the hitherto undocumented changes in the manufacturing technology, and the condition of the brick material in terms of conservation.
\end{abstract}

(c) 2017 Elsevier Ltd. All rights reserved.

\section{Introduction}

In 1925, the Material Test Committee of the Chinese Engineering Society provided some physical-mechanical data of modern bricks from six productive Shanghai brickmaking factories $[1,2]$. Surprisingly, those rare historical data go against the belief that water absorption usually reduces the compressive strength of a brick, despite the potential yet unrecognisable random errors during the experiment that might invalidate the data [3,4]. Moreover, by the mechanical data, the Chinese engineers stated that the modern new bricks were actually inferior to China's traditional 'blue

\footnotetext{
* Corresponding author.

E-mail addresses: shuchangxue@gmail.com (C.X. Shu), f.fratini@icvbc.cnr.it (E. Cantisani), klr@sdu.dk (K.L. Rasmussen), luisa.rovero@unifi.it (L. Rovero).
}

bricks' even though the latter having suffered over 1000 years of weathering. They ascribed this inferiority to the poor standards of the modern manufacturing system and questioned the wellassumed "progress" of civilisation in technology [2]. This argumentation has attracted very little attention until today. Conversely, engineers, architects, and builders (either Chinese or foreigners) have generally believed that the modern bricks were technically and artistically superior to the old ones, as written evidence and built materials both show, which is in contrast to the 1925 laboratory results in [2]. It is unclear whether or not the properties, deterioration and structural behaviours of the bricks produced in China are compatible with the theories and experiences in the western literature.

The traditional Chinese brickmaking and bricklaying are very different from European methods. Since the mid-19th century the old 
system has shifted to a new system of European mode in both production and use. During the transitional period Shanghai had a very high demand of European red bricks, which makes it be at the vanguard of the epochal shift. Therefore this study focuses on Shanghai, with a broader view on the contacts between China and the West.

Recent studies have revealed the complex mixture of all kinds of old and new blue bricks and red bricks in Shanghai's architecture during the transitional period $[3,15]$. However there are only a few analytical data about Shanghai cases $[9,10]$. Limited data about the properties of ancient bricks from other regions of China are published $[11,12]$. Our study follows these research questions:

- Firstly, the provenance of the bricks. The annually published statistics in the customs archive "Returns of Trade at the Treaty Ports in China," surprisingly, show that among the Chinese port cities Shanghai continuously imported the largest amount of bricks and tiles from foreign countries since 1864, and at least down to the year 1882; recorded origins include Great Britain, USA and Australia. At the same time Chinese blue bricks were exported to foreign countries, e.g. Japan. Where were these imported bricks used in Shanghai?

- Secondly, the progress of civilisation is being brought into question by historians of East Asian science and technology who pay attention to the heavy losses of traditional technology. However the discussions often lack scientific data. We doubt whether the properties of the traditionally-made bricks and the industriallymade modern bricks are comparable. This study thus aims at revealing the true conditions of the bricks, and collecting data for reconstructing the lost traditional technology as well as the real changes and developments in the modern time;

- Thirdly, we broadly observe the deterioration of bricks in Shanghai and the continuous loss of cohesion between the old materials and the restoration interventions. Restorations were often carried out on the surfaces of the brickworks $(1-2 \mathrm{~cm})$ after cleaning. What are the causes of the deterioration and the incohesion?

To make traditional blue bricks, a two-stage firing scheme employing oxidizing and reducing conditions was used in traditional kilns. Reducing conditions were achieved through injecting water into the kiln-chambers after an appropriate oxidizing firing, resulting in the 'blue' colour; this technology was still used in China up to the 1990s $[13,14]$. The reason for the reducing firing has long been an open issue. The literature on oriental ceramics usually hypothesizes that the reducing firing could improve the physicalmechanic properties of the fired ceramics and bricks [5-8].

Focusing on Shanghai, the chronology of the use of the bricks in architecture has been examined [3]. Data on the observable forms of the bricks (dimensions, colours, marks, textures) have also been preliminarily retrieved, and the present work was based on these data.

With regard to the comparable European architecture and analytical data [16-20], the present research deals with the compositional and technical characteristics of the brick samples responding to the above-mentioned three questions. The methodology follows the interdisciplinary strategies piloted in recent studies [21-25]. A determination of the maximum firing temperature was applied in this study [26]. Archival research, industrial records, archaeological and architectural methods were used in combination in order to recognize significant materials from architecture.

\section{Materials and analytical methodologies}

The samples came from four representative modern buildings, all listed as China's heritage sites. Their construction dates, ranging between 1866 and 1935, cover the main transitional period in the local brick history. (Table 1 and Figs. 1-3, the information of the samples in Table 2).

A sample of raw clay was taken with the help of the local brickmakers from Nanhui district on the outskirts of Shanghai City; it was used as a reference to define the origin of other brick samples, the fired brick sample B5 was made from this clay in a traditional kiln. We chose Nanhui clay because Nanhui is a remarkable place in terms of brickmaking, in either traditional system or modern industry. The famous "Da-Zhong Brick and Tile Factory" (19301990s) was situated in Nanhui and had significant influences from Belgian technology [27]. Sample "6 red" is a decayed fragment taken from the brickwork surface of the St Ignatius Cathedral, and was later revealed to be a restoration mortar by analyses.

Minor/non-destructive methods are ensured as much as possible on site. Most of the samples have mortars and/or plaster attached, from which the outward or inward surfaces of the bricks can be recognized. The exposed bricks in the two churches mainly suffer from salts (i.e. efflorescence), exfoliation and biological colonization.

The following investigations were performed:

- The mineralogical composition was determined on powder using an X-ray diffractometer (XRD) PANalytical X'PertPRO equipped with X'Celerator multirevelatory and High Score data acquisition and interpretation software ( $\mathrm{Cu}$ anticathode ( $\lambda=1.54 \AA$ ) was used, under the following conditions: current intensity of $30 \mathrm{~mA}$, voltage $40 \mathrm{kV}$, explored $2 \Theta$ range between 3 and $70^{\circ}$, step size $0.02^{\circ}$, time to step $50 \mathrm{~s}$, and scan speed of $0.04 \%$ s.);

- The clay mineral composition was determined on the fraction $<4 \mu \mathrm{m}$ extracted through sedimentation according to Stokes' law $[28,29]$ using a Philips PW 1729 diffractometer;

- The amount of $\mathrm{CaCO}_{3}$ was determined through the Gasometric technique, using a Dietrich Fruhling calcimeter [30];

- The chemical composition was determined using X-ray fluorescence (XRF). Samples were analysed using a wavelength dispersive X-ray fluorescence spectrometer Rigaku ZSX Primus II equipped with an end-window $4 \mathrm{~kW}$ Rh X-ray tube;

- The petrographic investigation was carried out through observation in transmitted light of thin sections ( $30 \mu \mathrm{m}$ thickness) with an Optical Microscopy (ZEISS Axioscope A1 microscope);

- The grain size distribution of the raw clay was carried out by sieving in order to separate the following fractions: sand $(\varnothing>63 \mu \mathrm{m})$, silt $(4 \mu \mathrm{m}<\varnothing<63 \mu \mathrm{m})$ and clay $(\varnothing<4 \mu \mathrm{m})$;

- Morphological and micro-chemical analyses were performed using an ESEM Quanta-200 FEI environmental scanning electronic microscope. The measurements were performed with an acceleration potential of $20 \mathrm{kV}$. The main working materials were backscattered electron images at high magnification (from 200X to 400X);

- The presence of salts was measured for the altered samples from the churches, Fourier transform infrared spectroscopy (FT-IR) spectra were collected with a portable Bruker Optics ALPHA FT-IR spectrometer in ATR mode, with a platinum single reflection diamond ATR module;

- The physical characteristics of the bricks were analysed. For each typology, three specimens of $2 \times 2 \times 2 \mathrm{~cm}$ were prepared to determine the water accessible porosity (effective porosity) (Pw\%) and the water absorption coefficient (I.C. w\%). A Mettler Toledo hydrostatic balance was used applying Archimede's law:

$$
\begin{aligned}
& \mathrm{V}_{\mathrm{w}}=\left(\mathrm{W}_{\mathrm{w}}-\mathrm{W}_{\mathrm{d}}\right) / \gamma_{\mathrm{w}} \\
& \mathrm{V}_{\mathrm{a}}=\left(\mathrm{W}_{\mathrm{w}}-\mathrm{W}_{\mathrm{h}}\right) / \gamma_{\mathrm{w}}
\end{aligned}
$$


Table 1

The architecture of the brick samples.

\begin{tabular}{|c|c|c|c|c|c|c|}
\hline CONSTRUCTION DATE & 1866-69 & $1905-10$ & 1920-30s & 1930-35 & $1931-35$ & $1960 s$ \\
\hline ARCHITECTURE & $\begin{array}{l}\text { Holy Trinity } \\
\text { Church (HTC) }\end{array}$ & $\begin{array}{l}\text { St. Ignatius } \\
\text { Cathedral (SIC) }\end{array}$ & $\begin{array}{l}\text { House at } 927 \\
\text { Huaihai Zhong Rd }\end{array}$ & Dalu Bank Store-house & Sihang Store-house & - \\
\hline $\begin{array}{l}\text { THE ORIGINAL BRICKS USED } \\
\text { FOR THE ARCHITECTURE }\end{array}$ & $\begin{array}{l}\text { Made in the } \\
\text { British } \\
\text { Settlement of } \\
\text { Shanghai with } \\
\text { British } \\
\text { facilities }\end{array}$ & $\begin{array}{l}\text { From a time } \\
\text { when the local } \\
\text { modern } \\
\text { brickmaking } \\
\text { industry started } \\
\text { to boom yet not } \\
\text { matured }\end{array}$ & $\begin{array}{l}\text { From a prosperous } \\
\text { time of brickmaking } \\
\text { at Shanghai }\end{array}$ & \multicolumn{2}{|c|}{$\begin{array}{l}\text { From the heyday of the modern } \\
\text { brickmaking industry at Shanghai }\end{array}$} & $\begin{array}{l}\text { Unused handmade } \\
\text { blue brick, fired in } \\
\text { traditional kiln in } \\
\text { Nanhui, Shanghai }\end{array}$ \\
\hline $\begin{array}{l}\text { STRUCTURE AND MATERIALS } \\
\text { IN ARCHITECTURE }\end{array}$ & $\begin{array}{l}\text { Brick } \\
\text { masonry, } \\
\text { stone } \\
\text { columns, } \\
\text { wooden roof }\end{array}$ & $\begin{array}{l}\text { Brick masonry, } \\
\text { wooden roof and } \\
\text { floor }\end{array}$ & $\begin{array}{l}\text { Brick masonry, } \\
\text { wooden roof }\end{array}$ & \multicolumn{3}{|c|}{$\begin{array}{l}\text { Column and flat beam system } \\
\text { in reinforced concrete, infill walls in bricks }\end{array}$} \\
\hline MASONRY CONDITION & $\begin{array}{l}\text { Solid exterior } \\
\text { walls neatly } \\
\text { bonded in red } \\
\text { bricks, } \\
\text { breadth } \\
\text { varies, min } \\
\text { dimension } \\
250 \mathrm{~mm}\end{array}$ & $\begin{array}{l}\text { Solid exterior } \\
\text { walls, neatly } \\
\text { bonded, outer } \\
\text { leaf in red bricks } \\
\text { inner leaf in blue } \\
\text { bricks, breadth } \\
\text { mostly in } \\
250 \mathrm{~mm}\end{array}$ & $\begin{array}{l}\text { Decayed brick } \\
\text { fragments from } \\
\text { outer wall, masonry } \\
\text { of high quality, } \\
\text { neatly bonded }\end{array}$ & \multicolumn{2}{|c|}{$\begin{array}{l}\text { Solid infill walls, neatly bonded, breadth in } \\
250 \mathrm{~mm} \text {, red and blue bricks are arranged } \\
\text { decoratively }\end{array}$} & \\
\hline ARCHITECTURE & $\begin{array}{l}\text { Anglican } \\
\text { church, } \\
\text { 'Gothic' and } \\
\text { 'Romanesque' } \\
\text { revival taste. } \\
\text { Received } \\
\text { interventions } \\
\text { over time }\end{array}$ & $\begin{array}{l}\text { Catholic } \\
\text { cathedral, } \\
\text { 'Gothic' revival. } \\
\text { With } \\
\text { interventions } \\
\text { over time }\end{array}$ & $\begin{array}{l}\text { Middle-class } \\
\text { terraced house. No } \\
\text { major interventions }\end{array}$ & \multicolumn{3}{|c|}{$\begin{array}{l}\text { Industrial building. 'International Style' with art- } \\
\text { deco details. Bombed in 1937, non-structural } \\
\text { walls damaged; received interventions afterwards }\end{array}$} \\
\hline
\end{tabular}

where: $W_{d}$ is the dry weight, $W_{w}$ is the wet weight at the saturation point, $\mathrm{W}_{\mathrm{h}}$ is the hydrostatic weight, $\mathrm{V}_{\mathrm{a}}$ is the volume of sample, $\mathrm{V}_{\mathrm{w}}$ is the volume of water inside the pores, $\gamma_{w}$ is the density of water at the measurement temperature.

The water accessible porosity was calculated as:

$\mathrm{Pw} \%=(\mathrm{Vw} / \mathrm{Va}) 100$

The water absorption coefficient I.C.w\% was calculated as:

I.C.W $\%=\left[\left(\mathrm{W}_{\mathrm{w}}-\mathrm{W}_{\mathrm{d}}\right) / \mathrm{W}_{\mathrm{w}}\right] 100$

- The maximum firing temperature was determined according to a method developed by the CHART group at the University of South Denmark: the magnetic susceptibility on a step-wise refired sample is measured [26]. The susceptibility data were plotted as a function of the re-heating temperature. In order to establish the firing temperature more accurately, the square of the first derivative was plotted as a function of the re-heating temperature. The first derivative was calculated as $\left(S_{i}-S_{i-1}\right) /$ $\delta \mathrm{T}$, where $S_{i}$ and $S_{i-1}$ are two consecutive susceptibility measurements and $\delta \mathrm{T}$ is the temperature difference;

- The mechanical investigation was conducted on the following bricks: B1, B2, B3, B4, B5, R1, R2. The bricks were cut to obtain cubic specimens in order to carry out compressive and indirect tensile tests. A total of 50 specimens were examined (Table 3 ).

Before performing the tests, each cubic specimen was visually assessed to evaluate the presence of irregular or nonhomogeneous surfaces. Irregular cubic specimens were capped with specific material in order to regularize the loading surfaces.

In the testing set-up, the uniaxial compression test on cubic specimens was carried out in agreement with [31]. Each specimen was placed under a universal press machine, type Instron 5590HVL, with $60 \mathrm{kN}$ loading cell. Tests were performed in displacements control by imposing constant vertical displacement at a rate of $0.6 \mathrm{~mm} / \mathrm{min}$. In all tests deformations were measured by the rel- ative displacement of the machine loading platens. An indirect tensile test was carried out in agreement with [32]. Cubic specimens were placed between two steel cylinders positioned axially at the top plate of the universal press, type Instron 5590-HVL, with $60 \mathrm{kN}$ loading cell.

\section{Results and discussion}

\subsection{Mineralogical-petrographic and physical characteristics}

The mineralogical and petrographic characteristics of the brick samples are listed in Tables 4 and 5, respectively. Table 6 shows the chemical analysis determined by XRF of the raw clay and brick samples.

As for the sound bricks, the mineralogical composition of red and blue brick (except B3) shows the presence of quartz and feldspars (Table 4). Hematite is sporadically present. B3 shows the presence of quartz and calcite.

Concerning the petrographic characteristics, the red bricks (R1, R2 and R3) show a similar aspect: slightly birefringent groundmass, fluidal texture with bands of different colour. In all samples the amount of framework is abundant, well sorted (grain size 10$30 \mu \mathrm{m}$ ) but not homogeneously distributed in the groundmass. The shape of grains is angular (quartz and feldspars) and plate (micas). Quartz, feldspars, micas are present in all the three bricks. The macroporosity is due to elongated pores along the bands (Fig. 4a).

The blue bricks B1, B2, B4 and B5 are quite similar among them: the groundmass is birefringent, the framework is abundant and homogenous in distribution, well sorted (grain size $10-30 \mu \mathrm{m}$ ). The grains have an angular shape and quartz, feldspars and micas are present in the composition (Fig. 4b).

The blue brick B3 shows completely different petrographic characteristics compared to the other blue bricks. The macroscopical aspect is variegated with black and white grains. Microscopically it shows a birefringent groundmass and a very abundant 

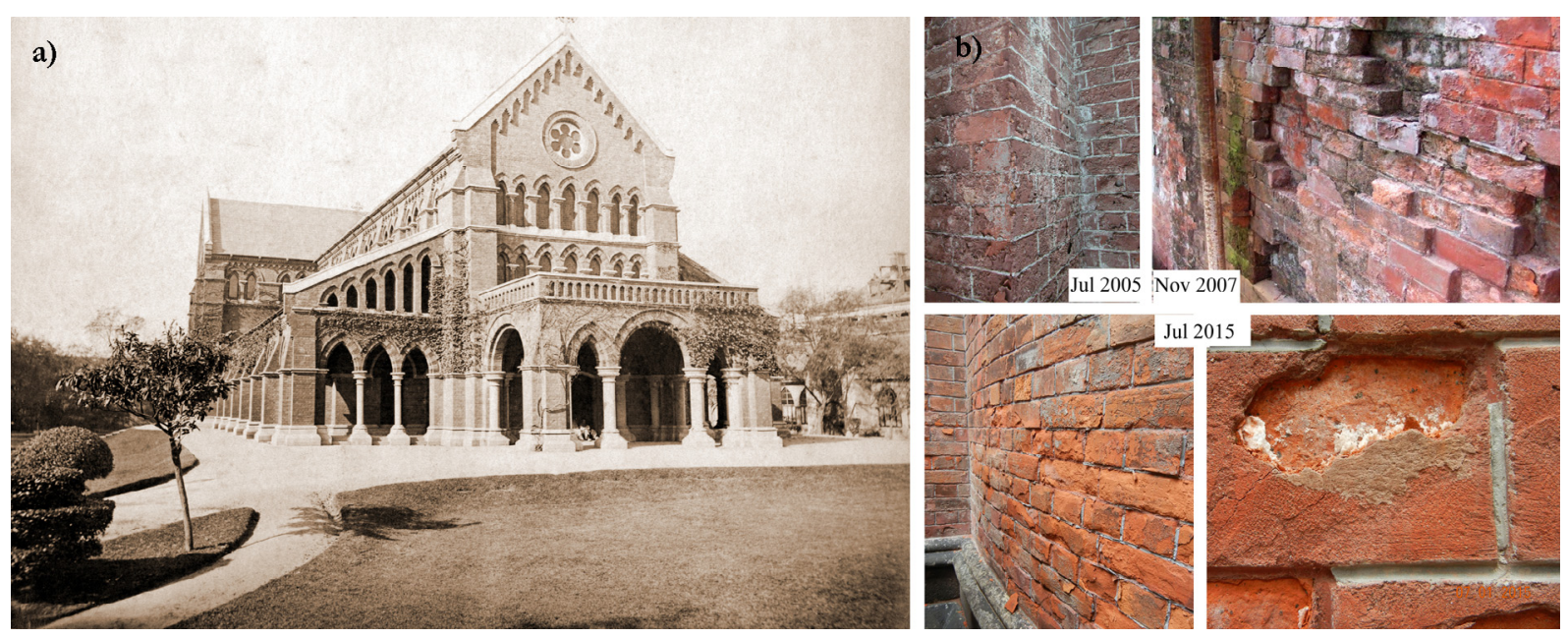

Fig. 1. a) Holy Trinity Church in the 19th century and b) the decay/deterioration over time.
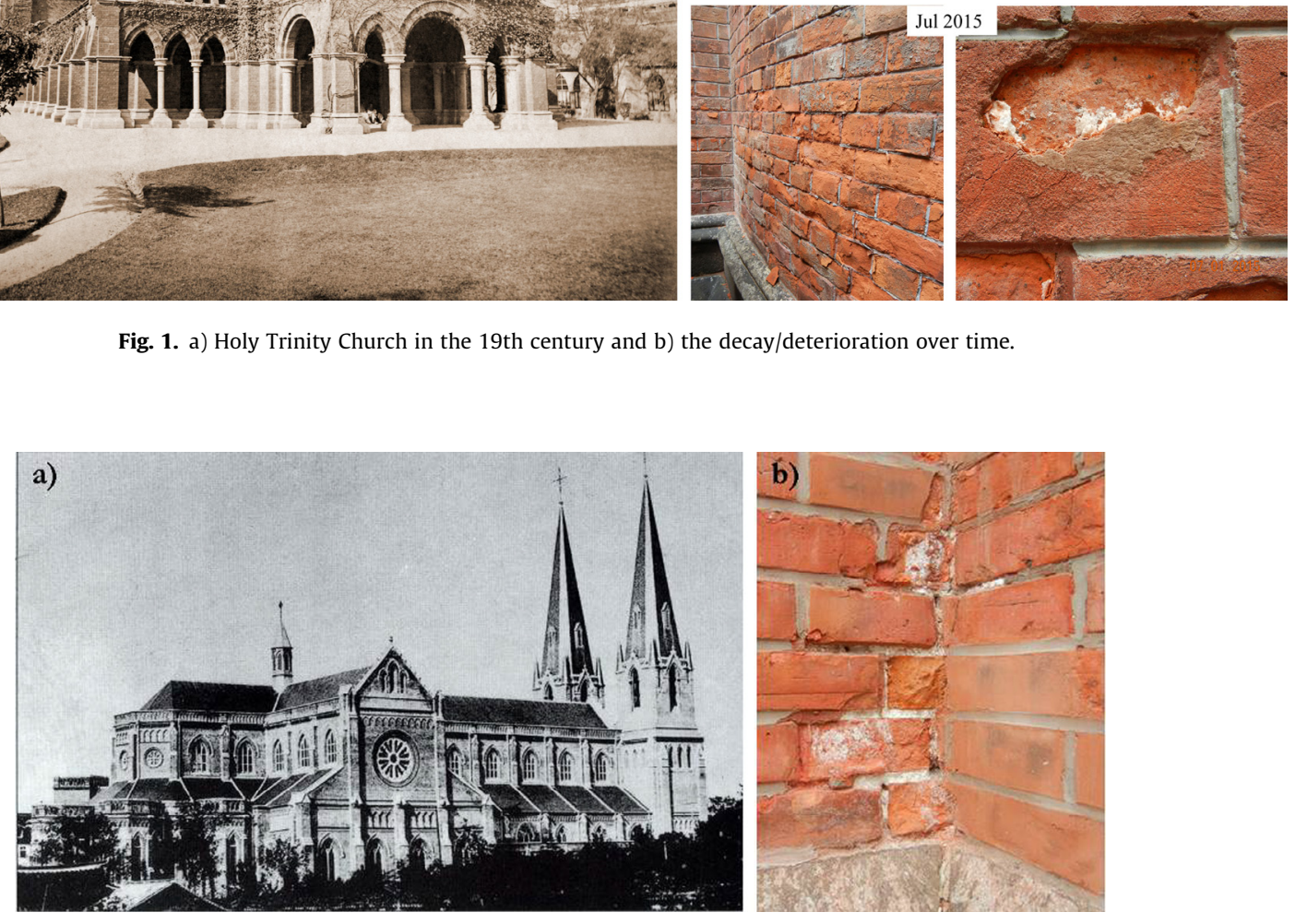

Fig. 2. a) St Ignatius Cathedral in 1910 and b) the decay in the façade in 2015.

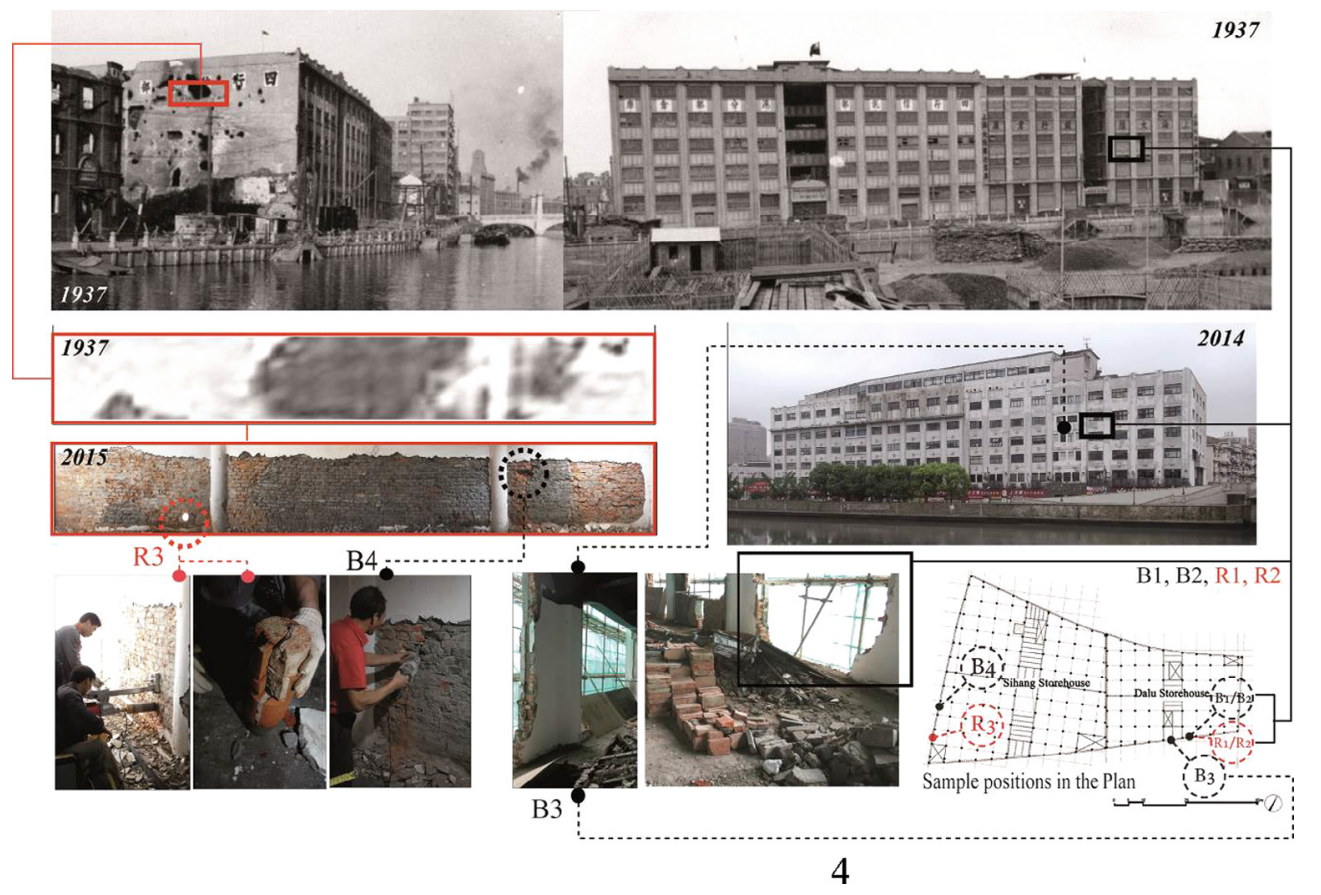

Fig. 3. Sihang and Dalu storehouses in 1937 and the sampling in 2015. 
Table 2

Brick sampling and macroscopic description.

\begin{tabular}{|c|c|c|c|c|c|}
\hline & Location & Dating the samples & Dimension [mm] & Types and textures & Picture \\
\hline B1 & Dalu Bank, south wall & Before 1935 & $255 \times 125 \times 45$ & $\begin{array}{l}\text { Grey with yellowish tinge, a darker core is } \\
\text { observed in section. Fine texture (coarser than } \\
\text { B5) }\end{array}$ & \\
\hline B2 & Dalu Bank, south wall & Before 1935 & $250 \times 125 \times 45$ & $\begin{array}{l}\text { Grey with creamy tinge. Fine texture (coarser } \\
\text { than B5) }\end{array}$ & \\
\hline B3 & Dalu Bank, south wall & $1954-83$ & $215 \times 105 \times 40$ & $\begin{array}{l}\text { Coarse with grains of varied colours in section, } \\
\text { from white-grey to black }\end{array}$ & \\
\hline B4 & $\begin{array}{l}\text { Sihang Warehouse, western } \\
\text { garble end (interior) }\end{array}$ & $1937-49$ & $\begin{array}{l}? \times 120 \times(47-50)[\text { half } \\
\text { cuboid] }\end{array}$ & $\begin{array}{l}\text { Grey with yellowish tinge, a little darker than } \\
\text { B1. Fine texture (coarser than B5) }\end{array}$ & \\
\hline B5 & $\begin{array}{l}\text { Unused blue brick fired in } \\
\text { traditional kiln in Nanhui, } \\
\text { Shanghai }\end{array}$ & $1960 \mathrm{~s}$ & $215 \times 112 \times 35$ & $\begin{array}{l}\text { Handmade, colour darker than B1, B2, B4, has } \\
\text { the finest texture in all the samples }\end{array}$ & \\
\hline R1 & Dalu Bank, south wall & Before 1935 & $255 \times 120 \times 55$ & $\begin{array}{l}\text { Brick mark 'LUN*HING', marbled texture in } \\
\text { section }\end{array}$ & \\
\hline $\mathrm{R} 2$ & Dalu Bank, south wall & Before 1935 & $255 \times 120 \times 53$ & $\begin{array}{l}\text { Brick mark 'LUN*HING', marbled texture in } \\
\text { section }\end{array}$ & \\
\hline R3 & $\begin{array}{l}\text { Sihang Warehouse, western } \\
\text { garble end (interior) }\end{array}$ & Before 1935 & Half cylinder shape & $\begin{array}{l}\text { Two pieces of brick, plaster attached. Marbled } \\
\text { texture, big cavity observed in section }\end{array}$ & \\
\hline 1 red & $\begin{array}{l}\text { HTC, north outer wall of the } \\
\text { nave, interior surface }\end{array}$ & 1866 & $\begin{array}{l}\text { Originally } \\
235 \times 120 \times 70\end{array}$ & Peeled-off brick powder & \\
\hline 2red & $\begin{array}{l}\text { HTC, outer wall of the apse } \\
\text { (southern part), exterior } \\
\text { surface }\end{array}$ & 1866 & $\begin{array}{l}\text { Originally } \\
235 \times 120 \times 70\end{array}$ & Already peeled-off brick powder & \\
\hline 3red & $\begin{array}{l}\text { HTC, inside a brick channel of } \\
\text { the south semi-transept }\end{array}$ & 1866 & $\begin{array}{l}\text { Originally } \\
235 \times 120 \times 70\end{array}$ & $\begin{array}{l}\text { Mud-like, scraped from the very soft red brick } \\
\text { surface inside the humid channel }\end{array}$ & \\
\hline
\end{tabular}

(continued on next page) 
Table 2 (continued)

\begin{tabular}{|c|c|c|c|c|c|}
\hline & Location & Dating the samples & Dimension [mm] & Types and textures & Picture \\
\hline 4red & $\begin{array}{l}\text { HTC, verandah to the } \\
\text { campanile }\end{array}$ & $\begin{array}{l}1893 \text { when the } \\
\text { campanile was } \\
\text { added? }\end{array}$ & Originally $235 \times 120 \times 70$ & Decayed surface of the brick, already peeled off & \\
\hline 5red & 927 Huaihai-zhong Rd & $1920-30 s$ & & Decayed fragments from modern red brick & \\
\hline 6red & St. Ignatius Cathedra, 1905-10 & Contemporary & & Fragment from brick surface, almost peeled off & \\
\hline
\end{tabular}

Table 3

Experimental program.

\begin{tabular}{llll}
\hline Brick & $\begin{array}{l}\text { Edges length of cubic } \\
\text { specimen }[\mathrm{mm}]\end{array}$ & $\begin{array}{l}\text { Specimens for } \\
\text { compression test } \\
{\left[\mathrm{n}^{\circ}\right]}\end{array}$ & $\begin{array}{l}\text { Specimens for } \\
\text { indirect tensile test } \\
{\left[\mathrm{n}^{\circ}\right]}\end{array}$ \\
\hline B1 & 40 & 4 & 3 \\
B2 & 40 & 6 & 3 \\
B3 & 40 & 3 & 3 \\
B4 & 40 & 1 & 1 \\
B5 & 30 & 8 & 4 \\
R1 & 40 & 4 & 3 \\
R2 & 40 & 4 & 3 \\
\hline
\end{tabular}

framework of bimodal granulometry (300-400 $\mu \mathrm{m}$ secondary, 1$2 \mathrm{~mm}$ principal) constituted by fired coal residues, rock and brick fragments (Fig. 5a, b).

The mineralogical and petrographic characteristics of R1, R2 R3, B1, B2, B4 and B5 highlight that the raw material used to produce these bricks was a layered silty clay.

The mineralogical and petrographic characteristics of B3 highlight show that the raw material used to produce this brick was a clay to which a large amount of temper appears to have been added. The authors are unsure about the original purpose of adding the non-clay mixtures - they might not (only) be used as a "temper". Moreover, it is not clear whether the reducing conditions were created through the traditional watering or by alternative methods. The maintenance of reducing firing is a core issue in making modern blue bricks with the new technology [14]. The mineralogical analysis of the raw clay shows the presence of quartz, feldspars (to be referred to the coarser fraction). The mineralogical analysis of the clay fraction show the presence of kaolinite (about 20\%), illite (about 35\%), illite-smectite (20\%), smectite (about 15\%), and chlorite (about 10\%). The grain size analysis showed $31 \%$ sand, $55 \%$ silt and $14 \%$ clay. According to these data the material can be classified as a sandy silt [33]. According to these data the material can be considered as a quite low plasticity earth.

As for the mineralogical analysis of altered bricks taken from the churches, 2red and 4red show the presence of quartz, feldspars and sporadic presence of gypsum. The petrographic observation of both samples show an isotropic groundmass, with an abundant and well-sorted framework (mean grain size 10-30 $\mu \mathrm{m}$ ) constituted by quartz and feldspars. The grains have an angular shape.

These characteristics highlight that the raw material used to produce 2red and 4red was quite similar to that used for R1, R2 and R3 but fired at higher temperatures as evidenced by the isotropic groundmass. Given that 2red and 4red came from a church dating back to 1866 , while R1, R2 and R3 came from a storehouse dating back to 1935 , this result deserves special attention. The

Table 4

XRD semiquantitative data of the main mineralogical composition.

\begin{tabular}{|c|c|c|c|c|c|}
\hline & Quartz & Feldspars & Hematite & Calcite" & Gypsum \\
\hline B1 & $\mathrm{xxx}$ & $\mathrm{xx}$ & $\mathrm{x}$ & - & - \\
\hline B2 & $\mathrm{xxx}$ & $\mathrm{xx}$ & $\mathrm{x}$ & - & - \\
\hline B3 & $\mathrm{x}$ & - & $\mathrm{x}$ & $9 \%$ & - \\
\hline B4 & $\mathrm{xxx}$ & $\mathrm{xx}$ & - & & - \\
\hline B5 & $\mathrm{xxx}$ & $\mathrm{xx}$ & - & - & - \\
\hline $\mathrm{R} 1$ & $\mathrm{xxx}$ & $\mathrm{xx}$ & - & - & - \\
\hline $\mathrm{R} 2$ & $x x x$ & $\mathrm{xx}$ & - & - & - \\
\hline R3 & $\mathrm{xxx}$ & $\mathrm{xx}$ & - & - & - \\
\hline 1 red & $\mathrm{xxx}$ & $\mathrm{x}$ & - & - & $\mathrm{xx}$ \\
\hline 2red & $\mathrm{xxx}$ & $\mathrm{xx}$ & - & - & $\mathrm{x}$ \\
\hline 3red & $\mathrm{xxx}$ & $\mathrm{x}$ & - & $\operatorname{tr}$ & $\mathrm{x}$ \\
\hline 4red & $\mathrm{xxx}$ & $\mathrm{xx}$ & - & - & - \\
\hline 5red & $\mathrm{xxx}$ & $\mathrm{x}$ & - & - & $\operatorname{tr}$ \\
\hline 6red & $\mathrm{xxx}$ & - & - & $11 \%$ & $\operatorname{tr}$ \\
\hline
\end{tabular}

$\mathrm{xxx}=$ high content; $\mathrm{xx}=$ medium content; $\mathrm{x}=$ low content .

calcimetry. 
Table 5

Petrographic description of samples.

\begin{tabular}{|c|c|c|c|c|c|c|c|c|c|}
\hline \multirow{2}{*}{$\begin{array}{l}\text { Sample } \\
\text { Name }\end{array}$} & \multicolumn{2}{|l|}{ Groundmass } & \multicolumn{6}{|l|}{ Framework } & \multirow[t]{2}{*}{ Porosity } \\
\hline & Appearance & Amount & Grain size & Sorting & ${ }^{*} \mathrm{Qz}$ & $\mathrm{Kf}$ & $\mathrm{Px}$ & Other & \\
\hline R1 & Slightly birefringent & Abundant & $10-30 \mu \mathrm{m}$ & Well sorted & $\mathrm{X}$ & $\mathrm{X}$ & - & Micas, hematite & Oriented \\
\hline R2 & Slightly birefringent & Abundant & $10-30 \mu \mathrm{m}$ & Well sorted & $\mathrm{X}$ & $\mathrm{X}$ & - & Micas, hematite & Oriented \\
\hline R3 & Slightly birefringent & Abundant & $10-30 \mu \mathrm{m}$ & Well sorted & $\mathrm{X}$ & $\mathrm{X}$ & - & Micas, hematite bonherz & Oriented \\
\hline B1 & Birefringent & Abundant & $10-30 \mu \mathrm{m}$ & Well sorted & $\mathrm{X}$ & $\mathrm{X}$ & - & Micas & Regular shape \\
\hline B2 & Birefringent & Abundant & $10-30 \mu \mathrm{m}$ & Well sorted & $\mathrm{X}$ & $\mathrm{X}$ & - & Micas & Regular shape \\
\hline B3 & Birefringent & Abundant & $300-400 \mu \mathrm{m} 1-2 \mathrm{~mm}$ & & & & & & \\
\hline B4 & Birefringent & Abundant & $10-30 \mu \mathrm{m}$ & well sorted & $\mathrm{X}$ & $\mathrm{X}$ & - & Micas & Regular shape \\
\hline B5 & Birefringent & Abundant & $10-30 \mu \mathrm{m}$ & Well sorted & $\mathrm{X}$ & $\mathrm{X}$ & - & micas & Oriented \\
\hline 2 red & Not birefringent & Abundant & $10-30 \mu \mathrm{m}$ & Well sorted & $\mathrm{X}$ & $\mathrm{X}$ & - & Micas & Irregular shape \\
\hline 3 red & Birefringent & Scarce & $10-30 \mu \mathrm{m}$ & Well sorted & $\mathrm{X}$ & $\mathrm{X}$ & - & Micas ${ }^{* *}$ ARF & Irregular shape \\
\hline 4 red & Not birefringent & Abundant & $10-30 \mu \mathrm{m}$ & Well sorted & $\mathrm{X}$ & $\mathrm{X}$ & - & - & Irregular shape \\
\hline 6 red & Not birefringent & Abundant & $10-30 \mu \mathrm{m} 200-400 \mu \mathrm{m}$ & Well sorted & $\mathrm{X}$ & $\mathrm{X}$ & - & - & Absent \\
\hline
\end{tabular}

${ }^{*} \mathrm{Qz}=$ quartz; $\mathrm{Kf}=\mathrm{K}$ feldspars; $\mathrm{Px}=$ pyroxenes

${ }^{* *}$ ARF $=$ argillaceous rock fragments.

Table 6

Chemical analysis by XRF expressed in wt\%.

\begin{tabular}{|c|c|c|c|c|c|c|c|c|c|}
\hline Oxide & Raw clay & B1 & B2 & B3 & B4 & B5 & $\mathrm{R} 1$ & $\mathrm{R} 2$ & R3 \\
\hline $\mathrm{Na}_{2} \mathrm{O}$ & - & 0.23 & 0.25 & - & 0.24 & 0.25 & 0.20 & 0.21 & 0.20 \\
\hline MgO & 1.04 & 0.97 & 0.98 & 0.23 & 0.99 & 0.97 & 1.00 & 0.98 & 1.02 \\
\hline $\mathrm{Al}_{2} \mathrm{O}_{3}$ & 10.61 & 13.28 & 13.29 & 14.86 & 13.27 & 13.30 & 12.95 & 12.97 & 12.93 \\
\hline $\mathrm{SiO}_{2}$ & 58.35 & 57.70 & 57.73 & 31.21 & 57.75 & 57.77 & 55.65 & 55.60 & 55.66 \\
\hline $\mathrm{P}$ & 0.56 & 0.38 & 0.40 & 0.33 & 0.40 & 0.42 & 0.34 & 0.33 & 0.32 \\
\hline S & 0.07 & 0.03 & 0.03 & 1.83 & 0.04 & 0.03 & 0.24 & 0.24 & 0.21 \\
\hline $\mathrm{K}_{2} \mathrm{O}$ & 6.10 & 5.62 & 5.64 & 1.30 & 5.62 & 5.65 & 5.74 & 5.77 & 5.75 \\
\hline $\mathrm{CaO}$ & 3.26 & 2.33 & 2.36 & 29.05 & 2.34 & 2.37 & 2.72 & 2.70 & 2.69 \\
\hline $\mathrm{Ti}$ & 1.39 & 1.22 & 1.24 & 1.74 & 1.26 & 1.25 & 1.27 & 1.27 & 1.25 \\
\hline $\mathrm{Cr}$ & 0.04 & 0.03 & 0.03 & 0.02 & 0.03 & 0.04 & - & - & - \\
\hline $\mathrm{MnO}$ & 0.26 & 0.40 & 0.39 & 0.10 & 0.38 & 0.38 & 0.40 & 0.38 & 0.37 \\
\hline $\mathrm{Fe}_{2} \mathrm{O}_{3}$ & 17.87 & 17.35 & 17.33 & 18.71 & 17.36 & 17.35 & 18.91 & 18.88 & 18.87 \\
\hline $\mathrm{Ni}$ & 0.02 & 0.04 & 0.03 & 0.03 & 0.04 & 0.03 & 0.03 & 0.03 & 0.05 \\
\hline $\mathrm{Cu}$ & 0.03 & 0.03 & 0.03 & 0.05 & 0.05 & 0.05 & 0.02 & 0.03 & 0.03 \\
\hline $\mathrm{Zn}$ & 0.17 & 0.03 & 0.04 & 0.02 & 0.03 & 0.05 & 0.08 & 1.00 & 0.08 \\
\hline As & & 0.01 & 0.01 & - & 0.01 & 0.02 & 0.01 & 0.02 & 0.01 \\
\hline $\mathrm{Rb}$ & 0.10 & 0.12 & 0.13 & 0.15 & 0.12 & 0.13 & 0.14 & 0.12 & 0.11 \\
\hline $\mathrm{Sr}$ & 0.06 & 0.06 & 0.04 & - & 0.05 & 0.05 & 0.04 & 0.04 & 0.03 \\
\hline $\mathrm{Zr}$ & 0.07 & 0.05 & 0.05 & 0.15 & 0.06 & 0.06 & 0.06 & 0.06 & 0.05 \\
\hline $\mathrm{Nb}$ & - & - & - & 0.25 & - & - & 0.15 & 0.14 & 0.13 \\
\hline $\mathrm{Cl}$ & - & - & - & - & - & - & 0.04 & 0.04 & 0.05 \\
\hline
\end{tabular}
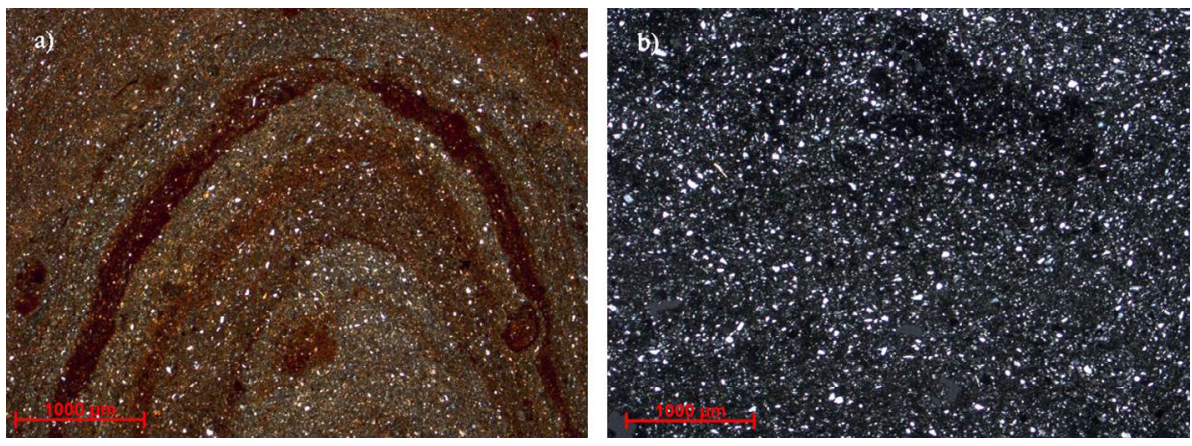

Fig. 4. a) Brick R2 and b) brick B4 in cross polarised light (XPL).

bricks from the 1866 church were made in an English brick company inside the former British Settlement of Shanghai [3].

As for sample 3red, the mineralogical analysis shows a composition similar to 2red and 4red samples. Nevertheless the petrographic observation shows a birefringent groundmass, with a scarce and well sorted framework (grain size 10-30 $\mu \mathrm{m}$ ) constituted by quartz, feldspars, micas and ARFs (argillaceous rock fragments). The grains have an angular shape. These characteristics highlight that the raw material used to produce 3red was quite similar to that used for R1, R2 and R3, fired more or less at the same temperature. The only difference is the presence of argillaceous rock fragments which points to a deficiency in seasoning the raw material. 3red comes from an unused brick deep inside a discarded channel structure attached to the outer wall of the south semitransept of the church. According to our architectural study, the channel was originally constructed for a heating system but seems never to have been used.

The mineralogical composition of the restoration mortar 6red shows the presence of quartz, calcite and traces of gypsum. The petrographic observation shows a groundmass slightly birefringent 

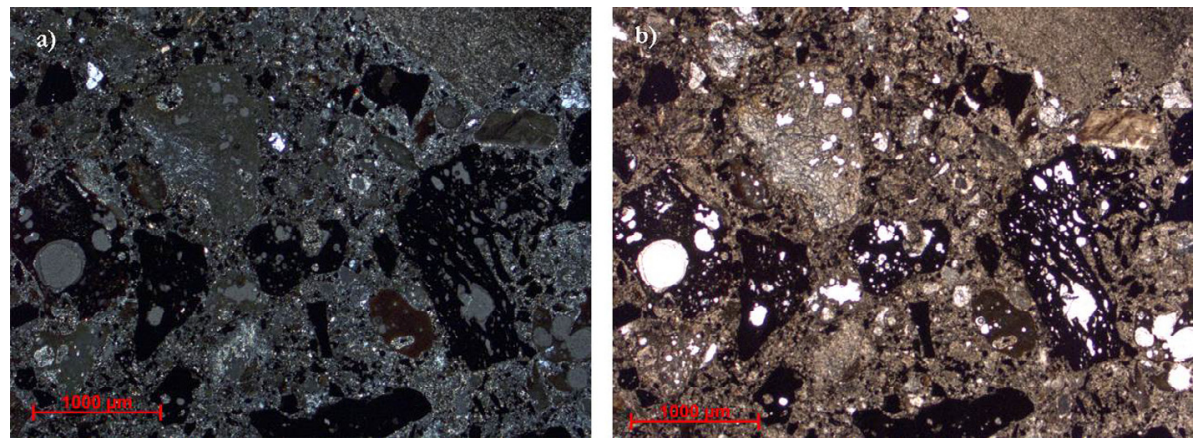

Fig. 5. a) Brick B3 in cross polarised light (XPL) and b) same image in plane polarised light (PPL).

with a very abundant framework homogenous in distribution. The grain size is bimodal (10-30 $\mu \mathrm{m}$ secondary, $200-400 \mu \mathrm{m}$ principal) (Fig. 6). The shape of the grains is angular. These characteristics suggest that 6red is not a fired brick but a restoration mortar obtained by mixing a very fine portion obtained by grinding bricks similar to R1, R2 and R3, a coarser fraction (200-400 $\mu \mathrm{m}$ in size) and a small amount of carbonatic binder (as confirmed by the presence of $11 \%$ of calcite).

Crystalline gypsum was frequently detected in the church samples by X-ray diffraction (Table 4) and FT-IR spectroscopy. The crystallization of gypsum can partially explain the deterioration observed in the brickwork (Fig. 1) and become a problem for conservation.

Table 6 shows the chemical analysis with XRF of the raw clay and B1, B2, B3, B4, B5, R1, R2, R3 samples.

The chemical composition of B1, B2, B4, B5, R1, R2, R3 samples is quite similar to that of the raw clay in terms of $\mathrm{Al}, \mathrm{Si}$ and $\mathrm{Ca}$. The B3 sample, instead, shows a higher amount of Ca and a lower amount of Si. The high content of Fe, comparable in all the samples analysed, is due to the presence of Fe oxides in the groundmass. Table 7 shows the physical characteristics of the brick samples.

Bricks R1, R2, R3 have a very similar water absorption coefficient and effective porosity, while bricks B1, B2, B3, B4, B5 have slightly different values. B4 has the maximum value of water absorption coefficient and effective porosity and B3 the lowest. Compared to the variability in the blue bricks, the tested red bricks have more consistent characteristics. R1, R2, R3 might come from the same factory $L U N^{*} H I N G$.

With regard to porosity, the literature data on European bricks made in the traditional method (hand moulding in soft paste) reports values ranging most commonly between 30 and $40 \%$, rarely up to $48 \%$ [34-37]. When made using the modern method (extru-

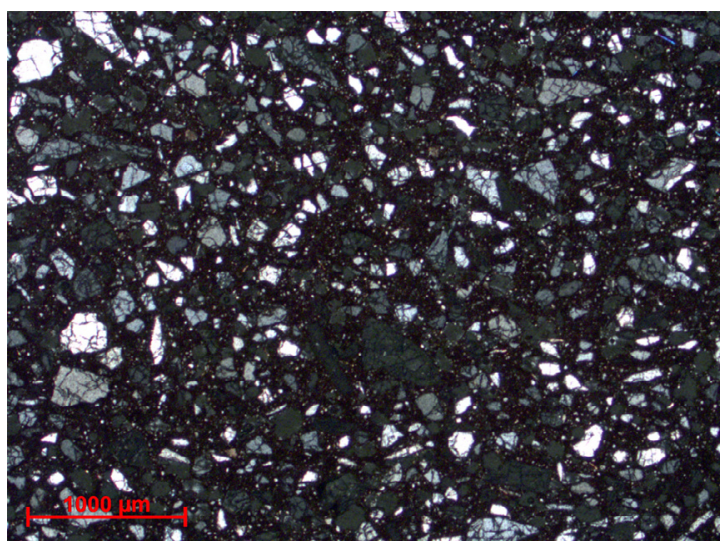

Fig. 6. Sample 6red in cross polarised light (XPL). sion), the porosity values are similar except for overfiring or fracturing due to shrinkage [38].

\subsection{Maximum firing temperature}

The maximum firing temperatures determined are listed in Table 8. The maximum firing temperatures are read from the graphs of the first derivative of the magnetic susceptibility with respect to re-heating temperature (Fig. 7). The original firing temperature is found a the first large deviation of the squared second derivative from zero. The original maximum firing temperatures are indicated with arrows in Fig. 8a and b. The uncertainty in the determination is 10 degrees $\mathrm{C}$ ( +-1 standard deviation).

These data are useful because it is thus possible to compare the petrographic characteristics of the red bricks and blue bricks with those of the raw clay fired at different temperatures. We observed that the microstructure of the groundmass of R1 was very similar to the raw clay fired at $900{ }^{\circ} \mathrm{C}$.

Except for B3 (Fig. 7b), the bricks were straightforward fired with maximum firing temperatures ranging from 610 to $910{ }^{\circ} \mathrm{C}$. These data clearly correlate with the different brickmaking methods for the various bricks: the blue bricks (samples B1, B2, B4, B5) exhibited relatively low firing temperatures, ranging between 610 and $810^{\circ} \mathrm{C}$, which were probably fired in traditional kilns (in fact we know that B5 was fired in a traditional kiln), and the same applies for the red brick $\mathrm{R} 3\left(790^{\circ} \mathrm{C}\right)$. Incorporating the architectural information (Table 1 ), we assumed that the two "LUN*HING" red bricks (samples $\mathrm{R} 1$ and $\mathrm{R} 2,910^{\circ} \mathrm{C}$ ) were probably fired in a modern kiln.

Brick B3 has two breaks in the susceptibility curve, which could be the result of an admixture of two components, one of which was pre-fired at $950{ }^{\circ} \mathrm{C}$, mixed into the clay and then fired at $830^{\circ} \mathrm{C}$. This result points to a production technology that added coal residues to the clay mixture, used both as temper and inner fuel (coal residue may contain unburned coal). As briefly mentioned in the local industrial history [24], coal residues have been used in brickmaking in Shanghai since 1934, with new technologies being developed in 1959. The new technology was promoted all over China since 1961, however the actual firing temperatures of the cinder bricks have not been well documented. A 1958 Chinese handbook on brickmaking provides a graph of the firing temperature and time required to make cinder bricks, showing that the highest point is about $950^{\circ} \mathrm{C}$. The handbook was translated from a Russian source [39].

Comparing the maximum firing temperature with the porosity, an inverse correlation is expected because the formation of a molten phase is produced with increasing temperatures, which occludes the pores. In this study no correlation was found. This can be explained by the maximum firing temperature being far 
Table 7

Physical characteristics.

\begin{tabular}{lllll}
\hline ID sample & ICw $(\%)$ & st dev & ${ }^{* *} \mathrm{Pw}(\%)$ & st dev \\
\hline R1 & 20.9 & 0.2 & 35.8 & 0.2 \\
R2 & 20.5 & 0.8 & 35.0 & 0.9 \\
R3 & 20.1 & 0.4 & 34.3 & 0.9 \\
B1 & 19.5 & 1.0 & 33.4 & 1.4 \\
B2 & 21.2 & 0.6 & 35.4 & 0.9 \\
B3 & 17.7 & 0.2 & 28.4 & 0.3 \\
B4 & 26.1 & 0.9 & 41.3 & 0.7 \\
B5 & 22.0 & 0.4 & 37.0 & 0.5 \\
\hline
\end{tabular}

${ }^{*} \mathrm{ICW}=$ water absorption coefficient.

$\mathrm{PW}=$ effective porosity.

Table 8

Maximum firing temperature of the bricks analysed.

\begin{tabular}{ll}
\hline & Max firing temperature $\left({ }^{\circ} \mathrm{C}\right)$ \\
\hline R1 & 910 \\
R2 & 910 \\
R3 & 790 \\
B1 & 770 \\
B2 & 810 \\
B3 & $950(830)$ \\
B4 & 670 \\
B5 & 610
\end{tabular}

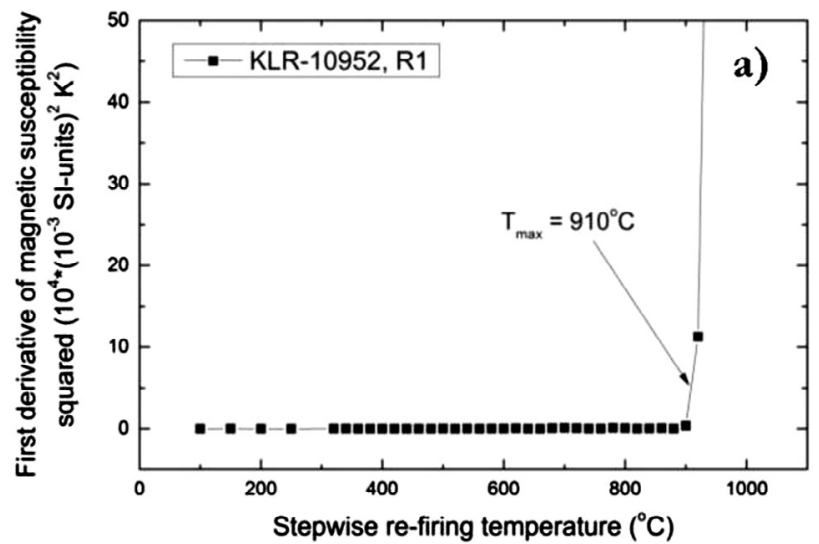

below the beginning of the melting process, and because we are comparing bricks from different productions.

\subsection{Mechanical characteristics}

\subsubsection{Uniaxial compression test}

For each specimen, a compressive stress-strain diagram was created. For each stress-strain diagram, the characteristic points were identified (Fig. 8a): Li, starting point of the linear segment; $\mathbf{L}$, end of the linear segment; $\mathbf{M}$, stress peak; L', intersection between the linear branch and the ordinate corresponding to the stress peak $\mathrm{M}$; $\mathbf{U}$, ultimate stress conventionally equal to $80 \%$ of $\mathrm{M}$.

In Fig. 8b the stress-strain diagram of brick R2.

The mechanical parameters were calculated using the values of the characteristic points: compressive strength $\sigma \mathrm{c}=(\mathrm{ym})$, tangent elastic modulus $\mathrm{E}=(\mathrm{yl}-\mathrm{yli}) /(\mathrm{xl}-\mathrm{xli})$, kinematic ductility $\mu \mathrm{c}=$ $\left(\mathrm{xm} / \mathrm{xl}^{\prime}\right)$ and available kinematic ductility $\mu \mathrm{cd}=(\mathrm{xu} / \mathrm{xm})$.

The average values of mechanical parameters are summarized in Table 9.

To facilitate the interpretation, the average values of the compressive strength and elastic modulus are reported in Figs. 9 and 10 using histograms that clearly represent the comparison between the different brick samples.

Concerning the compressive strength, the average values of the blue bricks (22 specimens) is $17.76 \mathrm{MPa}$ and that of the red bricks

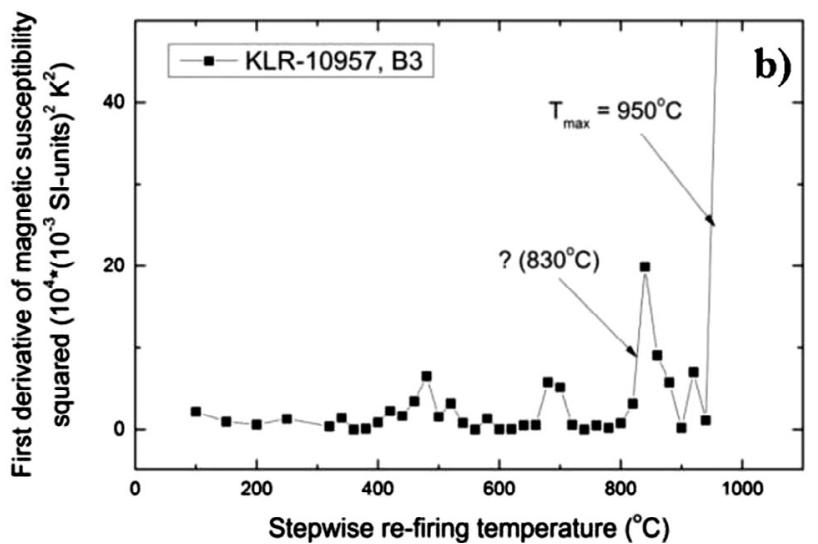

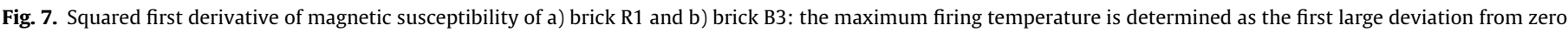
of the squared first derivative, and is indicated with an arrow.
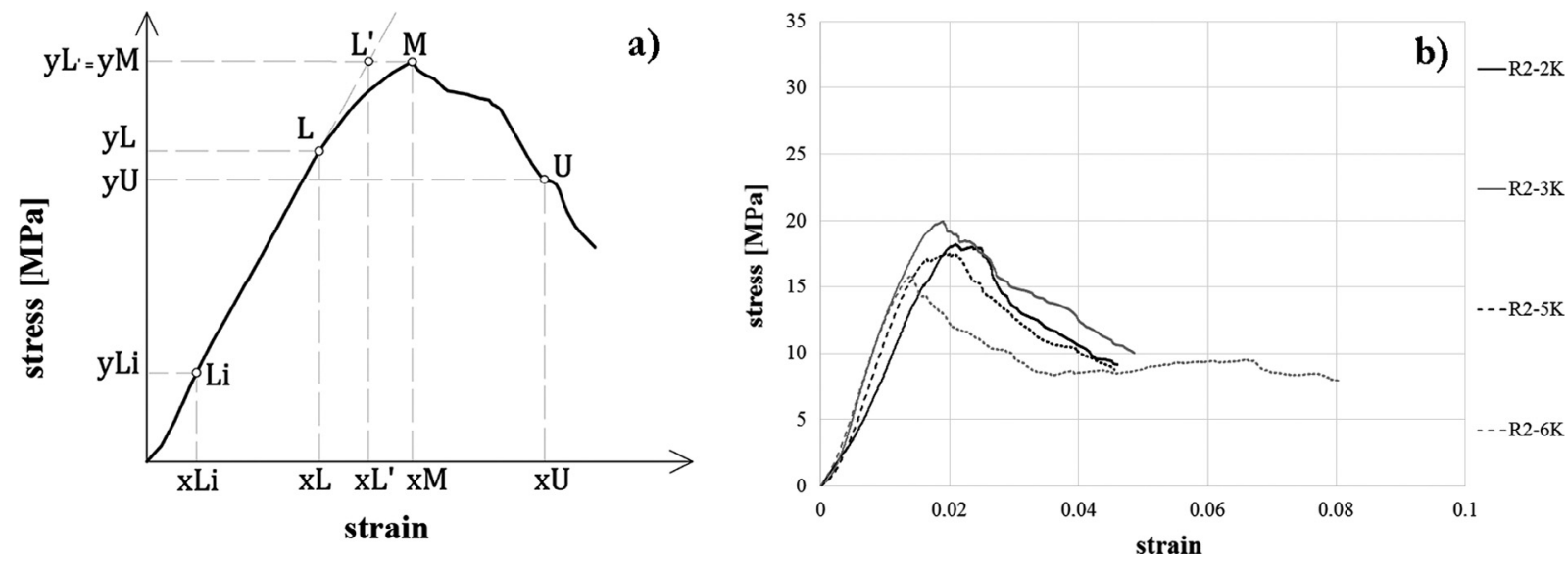

Fig. 8. a) Identification of the characteristic points in the stress-strain diagram; b) a stress-strain diagram of the specimens from brick R2. 
Table 9

Average values of mechanical parameters of the bricks analysed (the standard deviation and the coefficient of variation are reported in parentheses).

\begin{tabular}{|c|c|c|c|c|c|}
\hline Bricks & Compressive strength [MPa] & Tensile strength [MPa] & Elastic modulus [MPa] & Kinematic ductility & Available kinematic ductility \\
\hline B1 & 17.86 & 0.84 & 1491.66 & 1.29 & 1.49 \\
\hline (4 specimens) & $(1.95 ; 11)$ & $(0.22 ; 26)$ & $(369.38 ; 25)$ & $(0.13 ; 10)$ & $(0.25 ; 18)$ \\
\hline B2 & 17,49 & 0,81 & 1528,35 & 1,21 & 1,47 \\
\hline (6 specimens) & $(1.97 ; 11)$ & $(0.20 ; 25)$ & $(312.20 ; 20)$ & $(0.09 ; 7)$ & $(0.15 ; 11)$ \\
\hline B3 & 18,90 & 1,02 & 1090,74 & 1,32 & 1,33 \\
\hline (3 specimens) & $(1.51 ; 8)$ & $(0.41 ; 40)$ & $(113.80 ; 10)$ & $(0.10 ; 8)$ & $(0.08 ; 6)$ \\
\hline B4 & 11,06 & 0,11 & 553,63 & 0,82 & 1,45 \\
\hline (1 specimen) & /l & /I & /I & /I & /l \\
\hline B5 & 23.48 & 1.17 & 1421.47 & 1.22 & 1.18 \\
\hline (8 specimens) & $(3.64 ; 16)$ & $(0.26 ; 23)$ & $(563.34 ; 40)$ & $(0.30 ; 24)$ & $(0.26 ; 23)$ \\
\hline $\mathrm{R} 1$ & 22.66 & 0.81 & 1854.36 & 1.13 & 1.35 \\
\hline (4 specimens) & $(3.63 ; 17)$ & $(0.29 ; 36)$ & $(743.40 ; 48)$ & $(0.09 ; 8)$ & $(0.21 ; 16)$ \\
\hline $\mathrm{R} 2$ & 18,59 & 1,01 & 1346,69 & 1,26 & 1,38 \\
\hline (4 specimens) & $(1.47 ; 8)$ & $(0.42 ; 42)$ & $(182.84 ; 13)$ & $(0.13 ; 11)$ & $(0.04 ; 3)$ \\
\hline
\end{tabular}

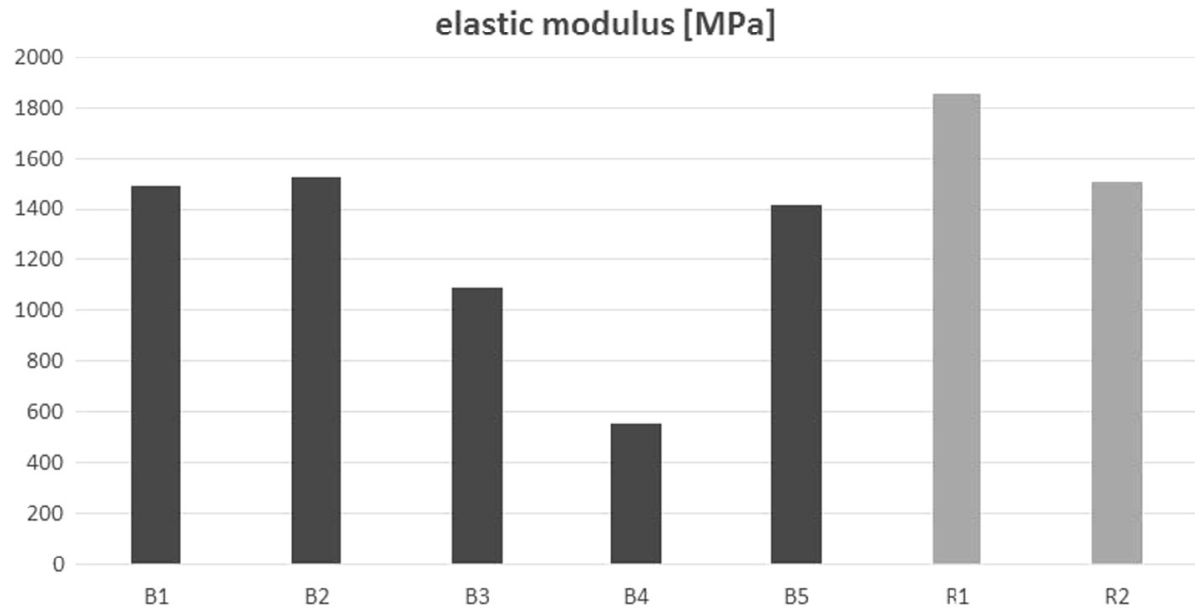

Fig. 9. Elastic modulus of the samples.

(8 specimens) is $20.63 \mathrm{MPa}$ : the strength of the red bricks is $14 \%$ greater than that of the blue bricks.

For each brick type, Table 9 shows that the average value of the indirect tensile strength is about $5 \%$ of the compressive strength. This result highlights the low value of the ratio of tensile strength on compressive strength; in fact modern handmade bricks pro- duced in Italy, and employed in an experimental analysis [40], exhibits a tensile strength about $10 \%$ of the compressive strength.

The average elastic modulus of the blue bricks is (22 specimens) $1217 \mathrm{MPa}$, and $1683 \mathrm{MPa}$ for the red bricks (8 specimens): the elastic modulus of the red brick is $28 \%$ higher than that of the blue brick.

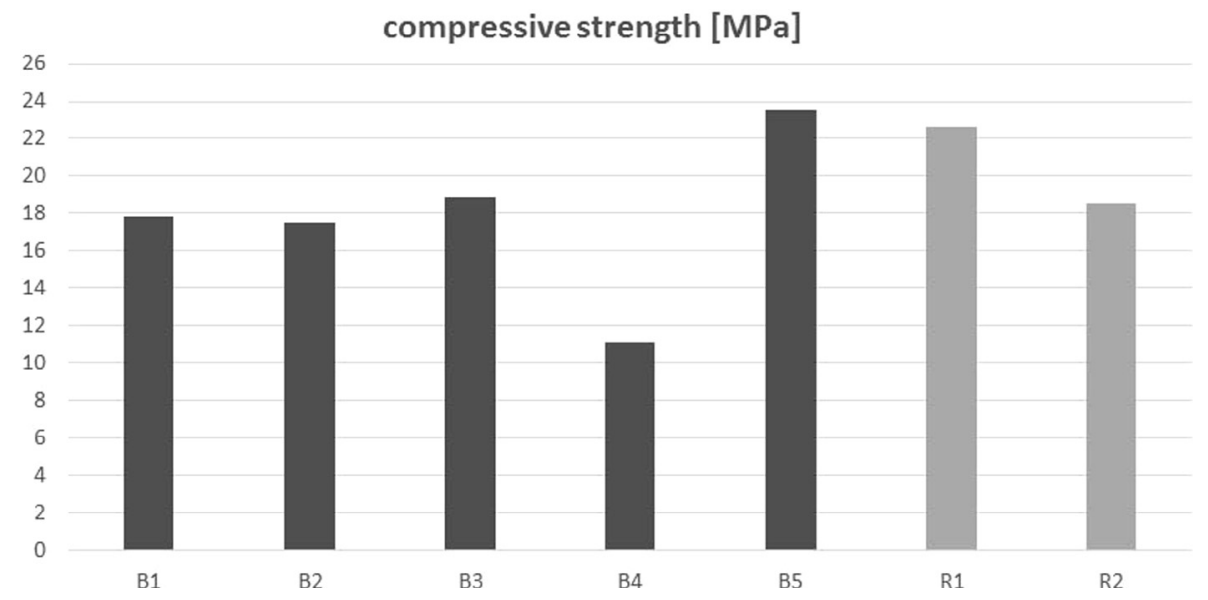

Fig. 10. Compressive strength of the samples. 
An inverse correlation is expected between the compressive strength and the porosity (see again Table 5). However, no full correlation was found except for B4, which shows a compressive strength (11.06 MPa), far lower than the other bricks and a far higher porosity (41\%). B1, B2, B5 and R2 have very similar mechanical properties, with a quite similar porosity. Despite the lowest porosity (28\%), B3 does not have the highest mechanical parameters. The incomplete correlation between the mechanical properties and porosity could be explained by the bricks originating from different productions. Fig. 11a and b show the brick specimens after compressive and tensile tests, respectively. Standard failure modes are shown for all types of bricks. Pseudo-vertical multi-cracking can be observed for the compression test and one vertical fracture between two cylinders for the indirect tensile test.

The mechanical parameters of the red bricks were compared with the mechanical parameters of bricks produced in Italy for the restoration (intervention on existing buildings) and mechanically tested by the authors in [40]. The elastic modulus of the Shanghai red bricks ( $1683 \mathrm{MPa}$ ) was found to be about the same as that of the Italian bricks (1780 MPa), but the compression strength $(20.63 \mathrm{MPa})$ was $16 \%$ greater than the Italian bricks (17.4 MPa).

\section{Conclusions}

Three crucial questions are raised regarding China's modern brick history and the present condition of old bricks. This study strategically sampled modern bricks used in Shanghai in the period 1866-1980s from famous church buildings and industrial buildings which are considered as Western heritage in China; it also sampled a local clay (Nanhui clay) from a representative brick industry area of Shanghai and a blue brick made from this kind of clay in a traditional local kiln as reference.

The analyses made it possible to establish that the different types of modern bricks sampled (except B3) were made from the same type of low plasticity clay (similar to the local clay analysed in this study) without addition of temper to the raw clay. Moreover the analyses confirm that the essential difference in manufacturing between the blue bricks and red bricks is due to the different reducing/oxidizing firing conditions.

Concerning the statement that the traditional reducing-firing stage could improve the physical-mechanical properties of the fired bricks, this study points out that the question is still open. Incorporating available data in the literature, it is dubitable to say that bricks fired through the two-stage scheme of oxidizingreducing conditions outperform bricks fired through purely oxidizing conditions at least not in terms of the mechanical and physical properties, or vice versa.

Compared to relevant Chinese references by compressive strength, our data are compatible with those of the bricks from six Shanghai factories dating back to 1925 (handmade blue bricks: 28.94 MPa; handmade red bricks: 15.18 and $26.64 \mathrm{MPa}$; industrially processed red bricks: $8.95,14.54$, and $24.75 \mathrm{MPa}$; all average values) [1]. Significantly, our samples, dating from 1935, exhibit values of compressive strength generally higher than the bricks from a building built 30 years earlier (blue bricks $8.35 \mathrm{MPa}$, red bricks $12.72 \mathrm{MPa}$ ) [9]. Our Shanghai bricks also exhibit roughly higher values than the ancient bricks from Pearl River region of Southeast China (6.69-10.29 MPa) [11] and from Yichun region of Central China (12.04 MPa, ordinary bricks for houses) [12]. These data suggest that the modern brickmaking industry of Shanghai was progressing in the long run, but during the transitional period 1840s-1910s it did not grow mature thus not ensuring stable qualities in red bricks.
As for a comparison with European bricks produced in the end 19th/early 20th century and with the moulding method of extrusion (extrusion was widely used in Shanghai as well, presumably applied to our samples), the mechanical and physical characteristics show values of the same order of magnitude with compressive strength between 10 and $20 \mathrm{MPa}$ and open porosity between 30 and $40 \%$.

An important discovery is the reconstruction of the clay mixture by adding coal residues, which was a very new technology to the Chinese. It can be dated back to 1934 in Shanghai and was greatly promoted over China from 1961. In the 1950s China's brick manufacture absorbed Russian sources including the technology of cinder bricks [39,41]. In China the form of cinder bricks seems to mimic the traditional blue brick, while in France the reuse of industrial residues seems an avant-garde trend in modern architecture [42].

Therefore, through the Shanghai cases, we do not consider the modern shift in China's brickmaking as a simple step forwards in terms of technological progress as the established industrial history has emphasized, instead, it is a rather complex modern process. We believe that Chinese bricks should be investigated without simply relying on the blue or red type classification.

Concerning today's conditions of conservation of the red bricks in historical buildings, the main problems are due to localised cases of gypsum crystallisation. This soluble salt could come from masonry mortars and/or from inside the bricks (possibly from the combustible because the raw clay does not show a significant presence of sulphur). Therefore, considering that the observed bad condition of conservation are strictly localized, we can generally affirm that the compositional, structural, and mechanical characteristics of the red bricks are well suited for the climatic conditions of Shanghai.

\section{Acknowledgements}

The Needham Research Institute at Cambridge UK supported and funded the archival research in 2015. The follow-up research has received funding from European Union's Horizon 2020 research and innovation program under the Marie SkłodowskaCurie grant agreement No 665501. Prof. Zheng Shiling from Shanghai provided important help in the sampling in Holy Trinity Church and St. Ignatius Cathedral, with the aid of CCC/TSPM (China Christian Council and National Committee of Three-Self Patriotic Movement of the Protestant Churches) and the Xufang Group, Ltd. Shanghai. The Research Center of Architecture, Urban and Culture under the Shanghai Institute of Architectural Design and Research Co., Ltd. gave us generous assistance in collecting materials from the Sihang and Dalu storehouses. We would like to thank CRIST (Centro di Cristallografia Strutturale) laboratories of the University of Florence for the chemical composition analysis of the bricks.

\section{References}

[1] H.X. Ling, P.B. Yang, K.H. Shi, Brick experiments. The first report of material test committee (Zhuantou shiyan, in Chinese), J. Chin. Eng. Soc. (Gongcheng: Zhongguo Gongcheng Xuehui Huikan, in Chinese) 1 (2) (1925) 150-168.

[2] H.X. Ling, P.B. Yang K.H. Shi, Report on the experiments of the bricks from Leifeng Pagoda (Shiyan baogao: Leifengta shiyan baogao, in Chinese), J. Chin. Eng. Soc. (Gongcheng: Zhongguo Gongcheng Xuehui Huikan, in Chinese) 1 (4) (1925) 312-315.

[3] C.X. Shu, The blue and the red: the plain brick wall in the architectural heritage of shanghai, 1866-1929 (unpublished PhD dissertation), Polytechnic of Milan, 2013.

[4] C.X. Shu, From the blue to the red: changing technology in the brick industry of modern Shanghai, in: Proceedings of the 5th International Congress on Construction History, vol. 3, Chicago: Lulu, 2015, pp. 313-320.

[5] Z.Z. Zhang, Y.R. Che, Y.F. Li, H.X. Sheng, A preliminary study on the ancient Chinese architectural ceramics (Jianzhu taoci de chu bu yanjiu, in Chinese), in: Shanghai Institute of CeramicsShanghai Institute of Ceramics (Ed.), Scientific and Technological Insights on Ancient Chinese Pottery and Porcelain 
(Zhongguo Gu Taoci Yanjiu, in Chinese), Science Press, Beijing, pp. 111-116.

[6] W.H. Yang, N.P. Xu, S.L. Miu, X. Xu, A study of ancient Chinese golden brick (Gudai jinzhuan de yanjiu, in Chinese), in: J.Z. Li , X.Q. Sun (Eds.), Proceedings of 1989 International Symposium on Ancient Ceramics (ISAC '89), Shanghai, Shanghai Scientific and Technological Literature Publishing House, 1992, pp. 305-311.

[7] J.Z. Li, History of science and technology in China, in: J.Z. Li (Ed.), Volume of ceramics (Zhongguo Kexue Jishu Shi, Taoci Juan, in Chinese), Beijing, Science Press, 1998.

[8] N.S. Li, J.G. Zhang, Z.W. Mao, M. Feng, C.S. Wang, The earliest architectural ceramic materials in China - "red fired clay" Excavated from Lingjiatan Site (Woguo zui zao de tao zhi jian cai - Lingjiatan hong tao kuai, in Chinese), J. Build. Mater. (Jianzhu Cailiao Xuebao, in Chinese) 7 (2) (2004) 127-132.

[9] W.P. Zhang, Q. Li, X.L. Gu, In-situ testing methods of mechanical properties of masonry materials in historical buildings (Lishi jianzhu qiti cailiao lixue xingneng xianchang jiance fangfa yanjiu, in Chinese), in: W.L. Jin (Ed.) Proceedings of the 2012 national conference on basic theory and engineering application of Chinese masonry structure, Hangzhou, Zhejiang University Press, 2012, pp. 87-94

[10] S.B. Dai, Studies on restoration technology of the envelope of historical buildings, Unpublished National project of science and technology, P.R. China, 2006-2011, Project No. 2006BAJ03A00.

[11] W.Z. Huang, L.P. Zheng, On the Strength rebound-curve of the Black brick from Ancient Buildings black brick (Gu jianzhu jiu qingzhuan huitan ce qiang quxian de jianli, in Chinese), Sci. Technol. Eng. (Kexue Jishu yu Gongcheng, in Chinese) 11 (13) (2011) 3111-3118.

[12] Q. Chun, Y.H. Dong, K. Van Balen, X.B. Xu, Experimental research on material properties of ancient white bricks in the Yichun Region, China, Int. J. Archit. Heritage (2016), http://dx.doi.org/10.1080/15583058.2016.1269376.

[13] Y.X. Song, The Exploitation of the Works of Nature / Tian Gong Kai Wu (Chinese), Shanghai Guji Chubanshe, Shanghai, 2008.

[14] R. Kerr, N. Wood, Ceramic technology, in: R. Kerr (Ed.), Science and Civilisation in China, vol. 5 part 12, Cambridge University Press, Cambridge, 2004.

[15] S.L. Zheng, The Evolution of Shanghai Architecture in Modern Times, Shanghai Education Press, Shanghai, 1999.

[16] AA.VV, Il mattone di Venezia, Stato delle conoscenze tecnico-scientifiche, in: Comune di Venezia (Ed.), Proceedings of the congress, Venice, 22-23 October. 1979.

[17] AA.VV, Le superfici dell'architettura: il cotto, Caratterizzazione e trattamenti, in: G. Biscontin, D. Mietto (eds.) Proceedings of the congress, Bressanone, June 30-July 3, 1992.

[18] G. Cultrone, I. Sidraba, E. Sebastiàn, Mineralogical and physical characterization of the bricks used in the construction of the "Triangul Bastion", Riga (Latvia), Appl. Clay Sci. 28 (2005) 297-308.

[19] P. Matysek, M. Witkowski, A comparative study on the compressive strength of bricks from different historical periods, Int. J. Archit. Heritage 10 (4) (2016) 396-405.

[20] P.B. Lourenço, F.M. Fernandes, F. Castro, Handmade clay bricks: chemical, physical and mechanical properties, Int. J. Archit. Heritage 4 (2010) 38-58.

[21] L. Rovero, U. Tonietti, F. Fratini, S. Rescic, The salt architecture in Siwa oasis Egypt (XII-XX centuries), Constr. Build. Mater. 23 (7) (2009) 2492-2503.

[22] F. Fratini, E. Pecchioni, L. Rovero, U. Tonietti, The earth in the architecture of the historical centre of Lamezia Terme (Italy), Characterization for restoration, Appl. Clay Sci. 53 (2011) 509-516.

[23] F. Sani, G. Moratti, M. Coli, P. Laureano, L. Rovero, U. Tonietti, N. Coli, Integrated geological-architectural pilot study of the Biet Gabriel-Rufael rock hewn church in Lalibela, northern Ethiopia, Ital. J. Geosci. 131 (2) (2012) 171-186.

[24] L. Rovero, F. Fratini, The Medina of Chefchaouen (Morocco): a survey on morphological and mechanical features of the masonries, Constr. Build. Mater. 47 (2013) 465-479.
[25] L. Rovero, V. Alecci, J. Mechelli, U. Tonietti, M. De Stefano, Masonry walls with irregular texture of L'Aquila (Italy) seismic area: validation of a method for the evaluation of masonry quality, Mater. Struct. 49 (6) (2016) 2297-2314.

[26] K.L. Rasmussen, G.A. de la Fuente, A.D. Bond, K.K. Mathiesen, S.D. Vera, Pottery firing temperatures: a new method for determining the firing temperature of ceramics and burnt clay", J. Archaeolog. Sci. 39 (2012) 1705-1716.

[27] Z.W. Jiang, Industrial records of building materials in Shanghai (Shanghai jianzhu cailiao gongye zhi, in Chinese), in: Z.W. Jiang (Ed.), Shanghai, Shanghai Shehui Kexue Yuan Chubanshe, 1997, pp. 122-136.

[28] C. Cipriani, Ricerche sui minerali costituenti le arenarie: I) sulla composizione mineralogica della frazione argillosa di alcune arenarie Macigno, Atti Soc. Toscana Sci. Nat. 65 (1958) 86-106.

[29] C. Cipriani, P.G. Malesani, Composizione mineralogica delle frazioni pelitiche delle Formazioni del Macigno e Marnoso-arenacea (Appennino settentrionale) Mem. Ist. Geol. e Min. 29 (1972) 1-25.

[30] G. Leone, L. Leoni, F. Sartori, Revisione di un metodo gasometrico per la determinazione di calcite e dolomite, Atti Soc. Toscana Sci. Nat. Mem. 95 (1988) 7-20.

[31] European Standard EN 772-1 - Methods of test for masonry units Determination of compressive strength, 2011.

[32] European Standard EN 12390-6 - Testing hardened concrete - part 6: tensile splitting strength of test specimens, 2010.

[33] F.P. Shepard, Nomenclature based on sand-silt-clay ratios, J. Sediment. Petrol. 24 (1954) 151-158

[34] F. Fratini, C. Manganelli Del Fà, E. Pecchioni, M. Matteini, A. Moles, M. Rizzi, Il Colosso dell'Appennino: studio delle malte e dei laterizi pertinenti la struttura ed il rivestimento, in: C. Danti, M. Matteini, A. Moles (Eds.), Le Pitture Murali: tecniche, problemi, conservazione, 59-72, Centro Di della Edifimi s.r.l, Firenze 1990.

[35] F. Fratini, R. Parenti, E. Pecchioni, I mattoni della Rocca di Montemass (Grosseto): un approccio interdisciplinare per la costruzione di un fossileguida. Rapporto preliminare, in: Proceedings of the congress, Bressanone, Libreria Progetto Editore, Padova, 5-8 July 1994, pp. 298-308.

[36] C. Manganelli Del Fà, F. Fratini, G. Ranocchiai, S. Briccoli Bati, Correlazioni tra caratteristiche mineralogico-petrografiche, proprietà fisiche e meccaniche d mattoni utilizzati nelle mura di Siena, Recuperare l'Edilizia: Arkos, 7 (1999) 81-85.

[37] S. Briccoli Bati, F. Fratini, G. Ranocchiai, Indagine comparativa sulle proprietà meccaniche di mattoni in pasta molle, in: Proceedings of the Workshop WONDER masonry Workshop on design for rehabilitation of masonry structures, Edizioni Polistampa, Florence, 6 April, 2006.

[38] F. Fratini, S. Ceccherini, N. Degl'Innocenti, C. Manganelli Del Fà, P. Malesani, Bricks: composition and physical characteristics as a function of the raw materials, in: Proceedings of the International RILEM/UNESCO Congress on Conservation of Stone and Other materials, Paris, June 29-July 1, 1993, pp. 740-747.

[39] I.A. Bulavin, P.D. Gonchar, Quick guide for the production of bricks and tiles (Zhuanwa shengchan jianming shouce, in Chinese), Beijing, China Building Engineering Press (Jianzhu Gongcheng Chubanshe), 1958, pp. 286-292 (translated from Russian).

[40] T. Rotunno, L. Rovero, U. Tonietti, S. Bati, Experimental study of bond behaviour of CFRP-to-brick joints, J. Compos. Constr. 19 (3) (2015) 4014063.

[41] Q.B. Wang, Theory and Practice of Fast Firing Bricks in Hoffmann Kiln (Lunyao Kuaisu Shaozhuan de Lilun yu Shijian, in Chinese), China Building Engineering Press (Jianzhu Gongcheng Chubanshe), Beijing, 1959.

[42] P.-A. Gatier, Restoration work at the Maison La Roche-Jeanneret, Paris, public lecture at Politecnico di Milano, 4 February 2016. 